\title{
CROSS-LINKED ENZYME AGGREGATES OF CATALASE FROM BOVINE LIVER
}

\author{
A. C. O. MAFRA ${ }^{1}$, W. KOPP ${ }^{1}$, M. D. RAMOS $^{1}$, M. B. BELTRAME ${ }^{1}$, M. P. A. RIBEIRO ${ }^{1}$, \\ A. C BADINO ${ }^{1}$ e P. W. TARDIOLI ${ }^{1, *}$ \\ ${ }^{1}$ Federal University of São Carlos, Chemical Engineering Department \\ *Corresponding author: Paulo W. Tardioli (pwtardioli@ufscar.br)
}

\begin{abstract}
Stabilization of multimeric enzymes is one of the major challenges in biocatalysis, because dissociation of subunits can inactivate the enzyme. Catalase (CAT; EC 1.11.16) is a homotetramer containing Fe-protoporphyrin IX in its active site. CAT breaks down hydrogen peroxide into water and molecular oxygen. In this study, crosslinked enzyme aggregates of bovine liver CAT (CAT-CLEAs) were prepared. The effects of precipitation and cross-linking on enzyme activity were studied. Thermal stability of free and immobilized enzyme were also evaluated at $40{ }^{\circ} \mathrm{C}$ and $\mathrm{pH} 7(200 \mathrm{~h})$. CAT-CLEAs were successfully prepared using ammonium sulfate and glutaraldehyde $(50 \mathrm{mM})$ as the precipitant and cross-linking agent, respectively. The best recovered activity obtained was $62 \%$. The derivative retained high activity along the stability test. The kinetic parameters values $\mathrm{v}_{\max }$ and $\mathrm{K}_{\mathrm{m}}$ were estimated as $11,350 \mathrm{U} / \mathrm{mg}$ and $66.7 \pm 10$ $\mathrm{mM}$ for the free CAT and $2,000 \mathrm{U} / \mathrm{mg}$ and $392 \pm 22 \mathrm{mM}$ for the CAT-CLEAs, respectively.
\end{abstract}

\section{INTRODUCTION}

Enzymes are proteins with catalytic functions, which play an important role in various biological and industrial chemical reactions. Enzymes are used in chemical conversions, biosensing, and bioremediation (Fagain, 2003). The great interest in enzymes by the industry is due to several factors. They act on a large variety of substrates and catalyzes a variety of complex reactions, on routes where the generation of waste and by-products is reduced (Brady and Jordaan, 2000). However, its use in some processes is often limited by its low operational stability and high cost. In the case of multimeric enzymes, where dissociation of the subunits often leads to enzyme inactivation and product contamination, it is necessary to stabilize its quaternary structure (Wilson et al., 2004; Fernandez-Lafuente, 2009).

Catalase (CAT; EC 1.11.16) is a homotetramer containing Fe-protoporphyrin IX in its active site (Fita and Rossman, 1985). CAT is usually obtained from bovine liver or from microbial sources. CAT from bovine liver has a molecular mass of $250 \mathrm{kDa}$ and each subunit has a molecular weight above $65 \mathrm{kDa}$ (Kiseler et al., 1967). CAT catalyzes the $\mathrm{H}_{2} \mathrm{O}_{2}$ (hydrogen peroxide) decomposition through Bi-Bi Ping-Pong mechanism. In the first step of the reaction, a molecule of $\mathrm{H}_{2} \mathrm{O}_{2}$ oxidizes the ion $\mathrm{Fe}^{3+}$ in the prosthetic group, with the condensation of one molecule of water. In the second step, a second molecule of $\mathrm{H}_{2} \mathrm{O}_{2}$ reduces the prosthetic group which was oxidized in the first step $\left(\mathrm{O}-\mathrm{Fe}^{4+}\right)$, generating $\mathrm{Fe}^{3+}$ and releasing $\mathrm{H}_{2} \mathrm{O}$ and $\mathrm{O}_{2}$ (Scandalios et al., 1997; Switala and Loewen, 2002; Adányi et al., 2007). 

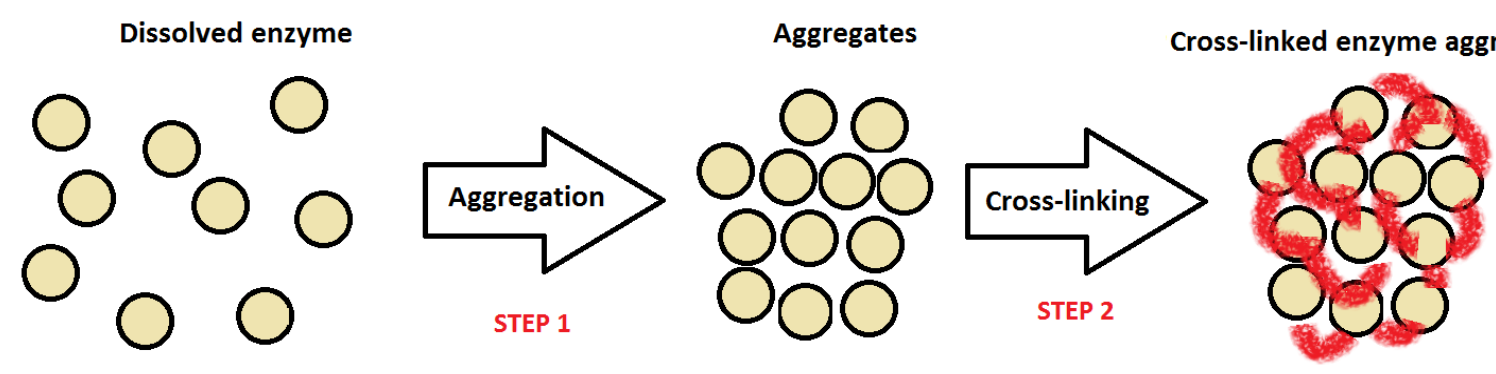

Figure 1 - Schematic representation of the preparation of cross-linked enzyme aggregates. In the first step, the soluble enzyme is aggregated by the action of a precipitant agent. In second step occurs the cross-linking by the addition of a cross-linker to the reaction medium

During the early 1960s, Doscher and Richards (1963) studied the cross-linking of dissolved enzymes through the reaction of amino groups with a bifunctional cross-linker, like glutaraldehyde, generating the cross-liked enzymes (CLE). However, CLE showed several drawbacks like poor reproducibility, low mechanical stability, low recovered activity, low volumetric activity and difficulties in handling. In a subsequent study, Quiocho and Richards (1964) investigated the cross-linking of a crystallized enzyme obtaining the cross-liked enzyme crystals (CLEC). Nevertheless, an enzyme to crystalize need to be highly pure, which greatly increases the process cost. Thereafter, Cao et al. (2000) developed a new way to immobilize enzymes, the cross-linked enzyme aggregates (CLEAs) (Schoevaart et al., 2004; Sheldon, 2007a), showed in Figure 1.

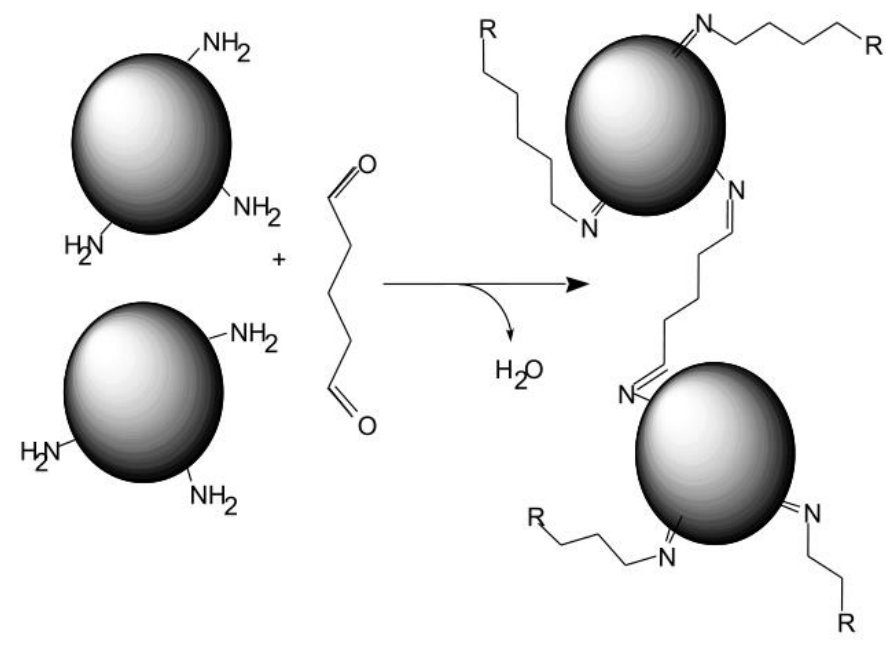

Figure 2 - Schiff base formation from the reaction of amino group of enzymes and carbonyl group of glutaraldehyde, during the cross-linking of aggregates

This methodology consists in the addition of salts, water-miscible organic solvents or nonionic polymers to an aqueous solution containing proteins. The proteins are precipitate as physical aggregates, without denaturation or perturbation of the tertiary structure. In order to keep the aggregates physically linked is necessary to perform the cross-linking (Cao et al., 2000). 


\section{9 a 22 de outubro de 2014 \\ Florianópolis/SC}

Glutaraldehyde is often used as low cost cross-linking agent. The cross-linking reaction occurs with a Schiff base formation between the free amino groups of lysine residues on the enzyme and the carbonyl group of glutaraldehyde, as showed in Figure 2. The concentration of the cross-linking agent is a sensitive parameter because an excessive concentration of the cross-linker can lead to the enzyme inactivation and a low concentration may result in an inefficient crosslinking (Schoevaart et al., 2004; Sheldon et al., 2007b).

Adsorption, encapsulation, entrapment and covalent binding (Kondo et al., 1993; Alptekin et al., 2008, 2009 and 2010; Itoh et al., 2009) have been used to immobilize CAT. However, Wilson et al. (2004) reported that these methods are difficult to stabilize the CAT quaternary structure. The authors have showed that the CLEAs methodology can stabilize CAT from bovine liver and from Micrococcus lysodeikticus.

In this context, the aim of this work was to investigate and optimize the preparation of CATCLEAs from bovine liver. Different precipitation (organic solvents and inorganic salts) and crosslinking agents were tested. CAT recovered activity was evaluated for all obtained derivatives. Kinetics of soluble CAT and CAT-CLEAs were estimated. Thermal stability of the biocatalyst was also addressed.

\section{MATERIAL AND METHODS}

\subsection{Material}

Bovine liver catalase $(5,140 \mathrm{U} / \mathrm{mg}$ protein) was obtained from Sigma-Aldrich (St. Louis, MO). Glutaraldehyde solution (25\% w/v) in $\mathrm{H}_{2} \mathrm{O}$, hydrogen peroxide $\left(\mathrm{H}_{2} \mathrm{O}_{2}\right)$, ammonium sulfate solution (AS), tert-butyl alcohol (TBA), polyethylene glycol (PEG), dimethoxyethane (DME) and acetone (A) were obtained from Sigma-Aldrich (St. Louis, MO). Other reagents were of analytical grade.

\subsection{CAT assay}

CAT-CLEAs and soluble CAT activities were determined spectrophotometrically at $240 \mathrm{~nm}$, following the decomposition of a $\mathrm{H}_{2} \mathrm{O}_{2}$ solution $\left(35 \mathrm{mM} \mathrm{H}_{2} \mathrm{O}_{2}\right.$ solution in $0.05 \mathrm{M}$ phosphate buffer, $\mathrm{pH} 7.5$ ) at $25^{\circ} \mathrm{C}$. One CAT unit was defined as the amount of enzyme that catalyzes the decomposition of $1 \mu \mathrm{mol}$ of $\mathrm{H}_{2} \mathrm{O}_{2}$ per minute.

\subsection{Protein concentration}

Lowry method was used to measure protein concentration in the enzyme preparations (LOWRY, 1951). The protein content (mg) was spectrophotometrically quantified at $750 \mathrm{~nm}$ using bovine serum albumin (BSA) as protein standard.

\subsection{Preparation of CLEAs}

CAT-CLEAs derivatives were prepared by dissolving CAT in sodium phosphate buffer (100 $\mathrm{mM}, \mathrm{pH}$ 7.0) to a final protein concentration of $40 \mathrm{mg} / \mathrm{mL}$. Protein aggregation was induced by mixing $1 \mathrm{~mL}$ of the enzymatic solution and $1 \mathrm{~mL}$ of precipitant (saturate solution of ammonium sulphate, tert-butyl alcohol, polyethylene glycol, dimethoxyethane and acetone). After 1 min of 
mixing, glutaraldehyde was added slowly to the final concentration of 50,100 or $200 \mathrm{mM}$. After 3 $\mathrm{h}$ of cross-linking reaction at $10{ }^{\circ} \mathrm{C}$, the suspension was centrifuged at $10,000 \times \mathrm{g}$ for $10 \mathrm{~min}$ at 4 ${ }^{\circ} \mathrm{C}$. CLEAs were recovered as pellet and washed with $100 \mathrm{mM}$ sodium phosphate buffer ( $\left.\mathrm{pH} 7.0\right)$. After preparation the enzyme was kept in the same buffer $(2 \mathrm{~mL})$ at $4{ }^{\circ} \mathrm{C}$ until use.

The recovered activity in CLEAs was calculated as follows:

Activity recovery $(\%)=($ Total activity of CLEAs in units/Total crude enzyme activity used for CLEAs Production in units) $\times 100$.

\subsection{Thermal stability study}

Thermal stability of soluble CAT and CAT-CLEAs were evaluated at $40{ }^{\circ} \mathrm{C}$ and $\mathrm{pH} 7.0(100$ $\mathrm{mM}$ sodium phosphate buffer) for $200 \mathrm{~h}$. In all assays, the initial activity was taken as $100 \%$.

\subsection{Kinetic analysis}

Kinetic parameters of soluble CAT and CAT-CLEAs were estimated by measuring initial reaction rates using different $\mathrm{H}_{2} \mathrm{O}_{2}$ concentrations ranging from $35 \mathrm{mM}$ to $280 \mathrm{mM}$, in sodium phosphate buffer $(0.1 \mathrm{M}, \mathrm{pH} 7)$ at $25{ }^{\circ} \mathrm{C}$. Michaelis-Menten kinetic parameters $\left(\mathrm{K}_{\mathrm{m}}\right.$ and $\left.\mathrm{v}_{\max }\right)$ of soluble CAT and CAT-CLEAs were calculated from nonlinear regression fitting using experimental data of initial reaction rates versus $\mathrm{H}_{2} \mathrm{O}_{2}$ concentrations.

\section{RESULTS AND DISCUSSION}

\subsection{Preparation of CAT-CLEAs}

Aiming to precipitate all protein in the reaction medium, several protein precipitants, organic solvents and an inorganic salt, were tested: tert-butyl alcohol (TBA); polyethylene glycol (PEG); dimethoxyethane (DME); acetone (A); and, ammonium sulfate (AS) were tested. At the same time, the effect of the cross-linker concentration (50, 100 and $200 \mathrm{mM}$ of glutaraldehyde) in the CAT-CLEAs final properties was investigated. Figure 3-A shows the recovered activity results to CAT-CLEAs prepared using five different precipitant agents and three different glutaraldehyde concentrations. Figure 3-B presents the residual activities to CAT-CLEAs after $200 \mathrm{~h}$ of at $40{ }^{\circ} \mathrm{C}$.

Using TBA as precipitant agent, the CAT-CLEAs retained around $40 \%$ of the offered activity. The best thermal stability (60\% of residual activity after $200 \mathrm{~h}$ ) was obtained by using $100 \mathrm{mM}$ of glutaraldehyde. CAT-CLEAs prepared using DME as precipitant agent and 50, 100, $200 \mathrm{mM}$ of glutaraldehyde retained almost $45 \%$ of the offered activity. Interestingly, for the lowest concentration of glutaraldehyde the biocatalyst showed the best result in the thermal stability (almost $50 \%$ of the initial activity was retained after $200 \mathrm{~h}$ at $40{ }^{\circ} \mathrm{C}$ ). For CAT-CLEAs prepared with PEG as precipitant agent, only the CAT-CLEAs prepared using $200 \mathrm{mM}$ of glutaraldehyde presented a good recovered activity, around $35 \%$. However, these CAT-CLEAs did not show good thermal stability. The highest recovered activity in CAT-CLEAs prepared with acetone as precipitant agent (around $30 \%$ ) was obtained by using $100 \mathrm{mM}$ of glutaraldehyde. These CAT-CLEAs presented residual activity of $70 \%$ after $200 \mathrm{~h}$ at $40{ }^{\circ} \mathrm{C}$. All CAT-CLEAs precipitated with ammonium sulfate present high stability at $40{ }^{\circ} \mathrm{C}$. The lowest glutaraldehyde concentration $(50 \mathrm{mM})$ was the best condition to preserve CAT activity during the CLEAs 
preparation $(62 \pm 0.2 \%)$. The CAT-CLEAs prepared using AS as precipitant was very stable, maintaining above $90 \%$ of the initial activity after $200 \mathrm{~h}$ at $40{ }^{\circ} \mathrm{C}$.
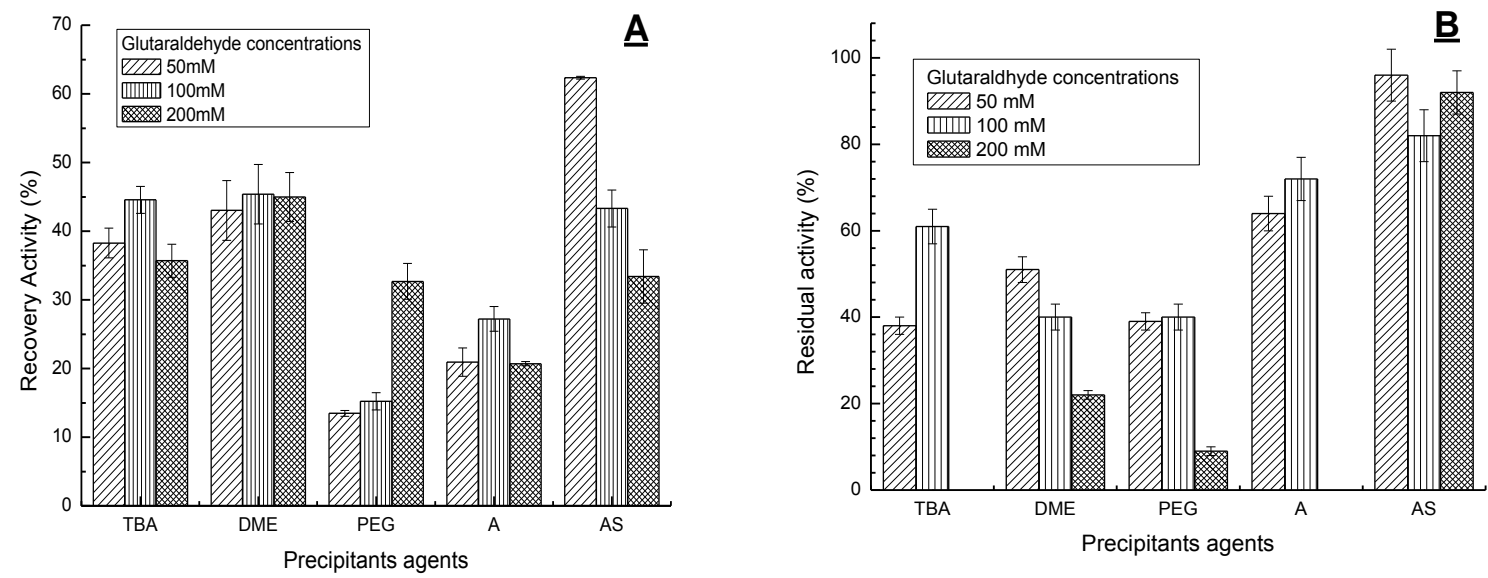

Figure 3 - (A) Recovered activity of CAT-CLEAs prepared by different precipitant agents: ammonium sulfate solution (AS), tert-butyl alcohol (TBA), polyethylene glycol (PEG), dimethoxymethane (DME), acetone (A) and different glutaraldehyde concentrations (50, 100, 200 $\mathrm{mM}$ ). (B) Residual activity of CAT-CLEAs after $200 \mathrm{~h}$ at $40{ }^{\circ} \mathrm{C}$

The best derivative prepared in the present work showed to be more active than the reported by Wilson et al. (2004). The authors immobilized CAT from bovine liver and from Micrococcus lysodeikticus by CLEAs technique using diethylene-glycol-dimethyl ether as precipitant agent and glutaraldehyde ( $5 \% \mathrm{v} / \mathrm{v}$ ) as cross-linking agent. Their derivatives retained 45 and $40 \%$ of activity, respectively. To our knowledge, this is the only work previously reported in the literature addressing immobilization of CAT by CLEAs technique that show recovered activity.

\subsection{Determination of kinetic parameters}

The best CAT-CLEAs prepared in this work was kinetically characterized. According to Chelikani et al. (2004) there are almost 16 types of CAT. These enzymes do not follow the classic model of Michaelis-Menten and they are inactivated at high concentration of $\mathrm{H}_{2} \mathrm{O}_{2}$. The classic kinetic model of Michaelis-Menten was fitted to the experimental data of initial reaction rate (in the range where inactivation by $\mathrm{H}_{2} \mathrm{O}_{2}$ is neglected) versus substrate concentration at $25{ }^{\circ} \mathrm{C}$ and $\mathrm{pH}$ 7.5 for soluble CAT and CAT-CLEAs, as shown in Figure 4. The values of kinetic parameters are presented in Table 1.

Table 1 - Kinetic parameters of free and immobilized CAT.

\begin{tabular}{ccc}
\hline CAT & $\mathbf{v}_{\max }(\mathbf{U} / \mathbf{m g}$ protein & $\mathbf{K}_{\mathbf{m}}(\mathbf{m M})$ \\
\hline Free & $11,350 \pm 175$ & $66.7 \pm 18$ \\
\hline Immobilized & $2,000 \pm 200$ & $392 \pm 22$ \\
\hline $\begin{array}{l}\mathbf{K}_{\mathbf{m}}: \text { Michaelis-Menten coefficient } \\
\mathbf{v}_{\text {max }}: \text { maximum reaction rate }\end{array}$ &
\end{tabular}



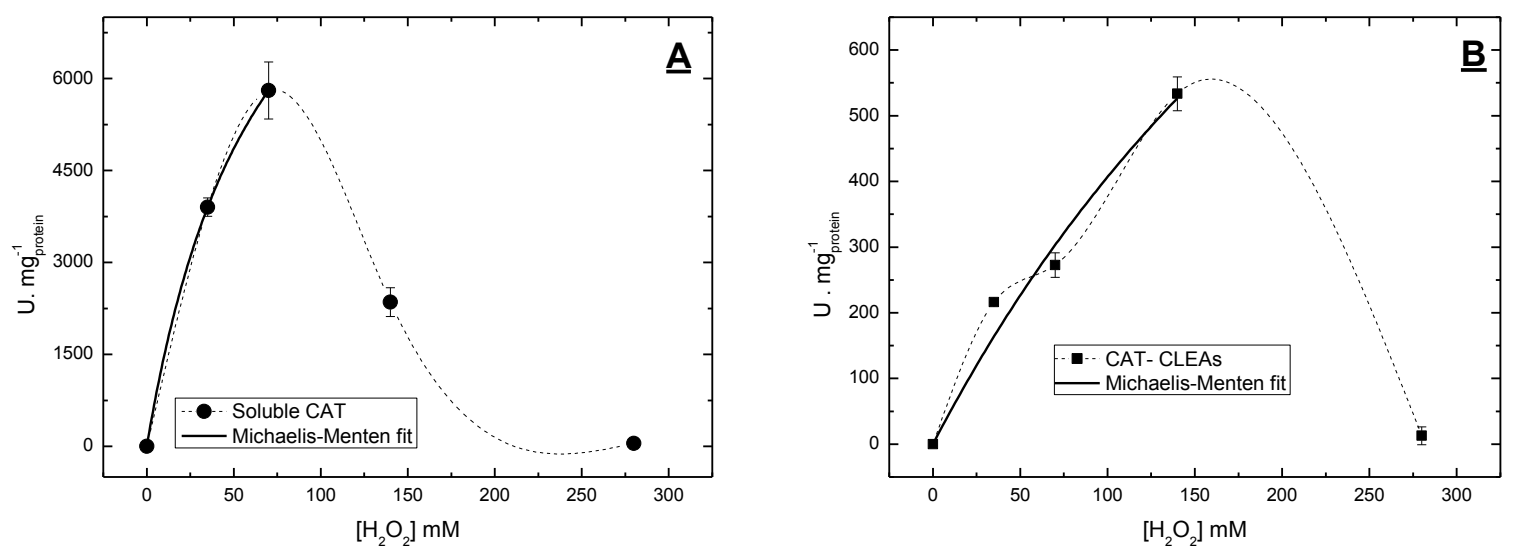

Figure 4 - Effect of $\mathrm{H}_{2} \mathrm{O}_{2}$ concentration on activities of : (A) soluble CAT and (B) CAT-CLEAs, at $25{ }^{\circ} \mathrm{C}$ and $\mathrm{pH}$ 7.5. The kinetic model of classic Michaelis-Menten was fitted to the experimental

data of initial reaction rate in concentration range $0-70 \mathrm{mM}$ for soluble CAT and 0-40 $\mathrm{mM}$ for immobilized CAT

The maximum velocity $\left(\mathrm{v}_{\max }\right)$ obtained for the CAT-CLEAs were only $16 \%$ of $\mathrm{v}_{\max }$ of soluble CAT. Reduction on $\mathrm{v}_{\max }$ parameter is commonly observed for immobilized enzymes. This reduction is mainly attributed to diffusional delays, steric hindrances, and conformational changes in the tridimensional structure. In fact, $\mathrm{v}_{\max }$ for CAT immobilized onto pore glass (Alptekin et al., 2009), cross-linked CAT in presence of bovine serum albumin, BSA (Tukel et al., 2013), and CAT immobilized on pHEMA-based membrane (Hidalgo et al., 2003) decreased to only $14 \%, 0.2$ $\%$ and $50 \%$ compared to the value of the free CAT, respectively. Tukel et al. (2013) investigated the effect of BSA as a feeder protein on the CAT-CLEAs activity. At the ratio of $10 \mathrm{mg} / \mathrm{mL}$ of CAT / $10 \mathrm{mg} / \mathrm{mL}$ of BSA the authors observed the highest activity of CAT-CLEAs. $\mathrm{K}_{\mathrm{m}}$ and $\mathrm{v}_{\max }$ values of CAT-BSA-CLEAs derivative were estimated from Lineweaver-Burk plots obtaining 43 $\mathrm{mM}$ and $41 \mathrm{U} / \mathrm{mg}$ protein, respectively.

$\mathrm{K}_{\mathrm{m}}$ values of free CAT and CAT-CLEAs were estimated as $66.7 \pm 18 \mathrm{mM}$ and $392 \pm 22 \mathrm{mM}$ $\mathrm{H}_{2} \mathrm{O}_{2}$, respectively. The large increase in the apparent $\mathrm{K}_{\mathrm{m}}$ may be due to diffusional delays. According to Sheldon (2007a), CLEAs form aggregates in a small volume that can be considered as a barrier to substrate diffusion. On the other hand, Ozyilmaz et al. (2007) immobilized bovine liver CAT covalently onto florisil activated with glutaraldehyde and they observed a $\mathrm{K}_{\mathrm{m}}$ value of $1722.0 \mathrm{mM} \mathrm{H}_{2} \mathrm{O}_{2}$. These authors also reported that a high $\mathrm{K}_{\mathrm{m}}$ value might be due to the production of oxygen gas into the pores of florisil, which might have hindered the reaction between CAT and $\mathrm{H}_{2} \mathrm{O}_{2}$ in aqueous phase. In this way, it is possible that this phenomenon has contributed to the high $\mathrm{K}_{\mathrm{m}}$ value observed in this work.

\section{CONCLUSIONS}

CAT was immobilized without carrier via cross-linking enzyme aggregates and the optimal immobilization conditions were determined. The precipitant agent and glutaraldehyde concentration were determined as ammonium sulfate and $50 \mathrm{mM}$ glutaraldehyde, respectively. Under optimal conditions, the CAT-CLEAs recovered $62 \%$ of the offered activity and showed 
high stability after $200 \mathrm{~h}$ at $40{ }^{\circ} \mathrm{C}$. CAT-CLEAs and free CAT were kinetically characterized. CAT-CLEAs showed low maximum reaction rate $\left(\mathrm{v}_{\max }\right)$ compared to the free enzyme. The catalyst prepared in this work was tolerant at high $\mathrm{H}_{2} \mathrm{O}_{2}$ concentrations and could be designed to be used in continuous process or fed-batch.

\section{ACKNOWLEDGMENT}

The authors thank CNPq and FAPESP for financial support.

\section{REFERENCES}

ADÁNYI, N.; BARNA, T.; EMRI, T.; MISKEI, M.; POCSI, I. Hydrogen peroxide producing and decomposing enzymes: their use in biosensors and other applications. Ind. enzymes. Section E, 441-459, 2007.

ALPTEKIN, O.; TUEKEL, S.; YILDIRIM, D.; ALAGOEZ, D. Characterization and properties of catalase immobilized onto controlled pore glass and its application in batch and plug-flow type reactors. J. Mol. Catal. B: Enzym. 58, 124-131, 2009.

ALPTEKIN, O.; TUEKEL, S.; YILDIRIM, D.; ALAGOEZ, D. Immobilization of catalase onto Eupergit C and its characterization. J. Mol. Catal. B: Enzym. 64, 177-183, 2010.

ALPTEKIN, O.; TUKEL, S. S.; YILDIRIM, D. Immobilization and characterization of bovine liver catalase on eggshell. J. Serb. Chem. Soc. 73, 609-618, 2008.

BRADY, D.; JORDAAN, J. Advances in enzyme immobilization. Biotechnol. Lett. 31:16391650, 2009.

CAO, L.; VAN RANTWIJK, F.; SHELDON, R. Cross-Linked Enzyme Aggregates: A Simple and Effective Method for the Immobilization of Penicillin Acylase. Org. Lett. 2, 1361-1364, 2000.

CHELIKANI, P.; FITA, I.; LOEWEN, P. C. Diversity of structures and properties among catalases. CMLS, Cell. Mol. Life Sci. v. 61, p.192-208, 2004.

DOSCHER, M. S.; RICHARDS, F. M. The activity of an enzyme in the crystalline state: Ribonuclease S. J. Biol. Chem. 238, 2399-2406. 1963.

FÁGÁIN, C. O. Enzyme stabilization-recent experimental progress. Enzyme Microb. Technol. 33, 137-149, 2003.

FERNANDEZ-LAFUENTE, R. Stabilization of multimeric enzymes: Strategies to prevent subunit dissociation. Enzyme and Microbial Technology. 45, 405-418, 2009.

FITA, I.; ROSSMAN, M. G. The active center of catalase. J. Mol. Biol. 185, 21-37, 1985.

HIDALGO, A.; BETANCOR, L.; LÓPEZ-GALLEGO, F.; MORENO, R.; BERENGUER, J.; FERNÁNDEZ-LAFUENTE, R.; GUISÁN, J. M. Preparation of a versatile biocatalyst of immobilized and stabilized catalase from Thermus thermophilus. Enzyme Microb. Technol. 33:278-285, 2003.

ITOH, T.; ISHII, R.; MATSUURA, S.; HAMAKAWA, S.; HANAOKA, T.; TSUNODA, T.; MIZUGUCHI, J.; MIZUKAMI, F. Catalase encapsulated in mesoporous silica and its performance. Biochem. Eng. J., 44, 167-173, 2009.

KISELER, N. A.; SPITZBERG, C. L.; VAINSTEIN, B. K. J. Mol. Bin. 25,433, 1967. 
KONDO, A.; MURAKAMI, F.; KAWAGOE, M.; HIGASHITANI, K. Kinetic and circular dichroism of enzymes adsorbed on ultrafine silica particles. Appl. Microbiol. Biotechnol. 39:726731, 1993.

LOWRY, O. H.; ROSEBROUGH, N. J.; FARR, E. L.; RANDALL, R. J. Protein measurement with the folin phenol reagent. J. Biol. Chem.193 (1): 265-75, 1951.

OZYILMAZ, G.; TUKEL, S. S.; ALPTEKIN, O. Kinetic properties and storage stability of catalase immobilized on to florisil. Indian J. Biochem Biophys. 44(1):38-43, 2007.

QUIOCHO, F. A.; RICHARDS, F. M. Intermolecular cross-linking of a protein in the crystalline state: Carboxypeptidase A. Proc. Natl. Acad. Sci. USA 52:833-839, 1964.

SCANDALIOS, J. G.; GUAN, L.; POLIDOROS, A. N. Catalases in plants: gene structure, properties, regulation, and expression, in oxidative stress and the molecular biology of antioxidant defenses. Cold Spring Harbor Laboratory Press, pp. 343-406 ,1997.

SCHOEVAART, R.; WOLBERS, M. W.; GOLUBOVIC, M.; OTTENS, M.; KIEBOOM, A. P. G.; VAN RANTWIJK, F.; VAN DER WIELEN, L. A. M.; SHELDON, R. A. Preparation, optimization, and structures of cross-linked enzyme aggregates (CLEAs ). Biotechnol. Bioeng. 87(6), 754-762, 2004.

SHELDON, R. A. Immobilization of enzymes as cross - linked enzyme aggregates: a simple method for improving performance. Biocatal. Pharm. Biotechnol. Ind., 351-362, 2007a.

SHELDON, R. A.; SORGEDRAGER, M.; JANSSEN, M. H. A. Use of Cross-linked Enzyme aggregates (CLEAs) for performing biotransformations. Chemistry Today, 25 (1), 48-52, $2007 \mathrm{~b}$.

SWITALA, J.; LOEWEN, P. C. Diversity of properties among catalases. Arch. Biochem. Biophys. v. 401, p.145-154, 2002.

TÜKEL, S. S.; HÜRREM, F.; YILDIRIM, D.; ALPTEKIN, O. Preparation of crosslinked enzyme aggregates (CLEA) of catalase and its characterization. Journal of Molecular Catalysis B: Enzymatic, 97, 252- 257, 2013.

WILSON, L.; BETANCOR, L.; FERNANDEZ-LORENTE, G.; FUENTES, M.; HIDALGO, A.; GUISAN, J. M.; PESSELA, B. C. C.; FERNANDEZ-LAFUENTE, R. Crosslinked aggregates of multimeric enzymes: A simple and efficient methodology to stabilize their quaternary structure. Biomacromolecules, 5(3), 814-817, 2004. 